\title{
Repertorio teatral e internacionalización del teatro chileno: un estudio de caso ${ }^{1}$
}

\section{Theatrical Repertoire and Internationalization of Chilean Theater: Case Study}

\author{
Pía Salvatori \\ Dipartimento di Lingue, Letterature e Studi Interculturali, Universidad de Firenze. \\ Firenze, Italia. \\ piafabiola.salvatorimaldonado@unifi.it
}

\section{Resumen}

La internacionalización del teatro es un fenómeno de reciente preocupación en los Estados latinoamericanos, ya que propicia, la visibilidad cultural de los países y el intercambio artístico y crítico, además de nuevas posibilidades económicas. Tal circulación internacional de obras teatrales supone la creación de un repertorio que llamaré "repertorio de exportación", a través del cual se proyecta una imagen cultural del país de procedencia, en tanto resultado de una construcción mediada por una selección. A través del estudio de un grupo de obras chilenas presentadas en el extranjero es posible observar las convergencias y divergencias de dicho repertorio, identificar los diversos aspectos implicados en la circulación internacional y reflexionar acerca de la imagen cultural proyectada por el teatro.

Palabras clave: internacionalización, repertorio, teatro chileno, generación de postdictadura.

\section{Abstract}

Theater internationalization is a phenomenon of recent concern in Latin-American regions. This internationalization favors countries' cultural visibility and artistic and critic exchange as well as new economic benefits, among others. International circulation of theatrical plays leads to the creation of a repertoire -which I call an "exportation repertoire"-, that projects a cultural image of the country of origin. This image emerges as a result of a construction mediated by selection. The study of chilean plays presented abroad allows to observe the coincidences or divergences of the repertoire, identify different aspects involved in international circulation and meditate about the cultural image projected by theater.

Keywords: internationalization, repertoires, chilean theater, post-dictatorship generation.

1 El presente artículo forma parte de una investigación de tesis doctoral realizada con el aporte de la Comisión Nacional de Investigación Científica y Tecnológica CONICYT. Agradezco a los directores, actores y dramaturgos de las compañías en estudio por la apertura y disponibilidad para proporcionarme los textos de las producciones y el material audiovisual. 


\section{Introducción}

En este artículo nos proponemos abordar la emergente internacionalización del teatro chileno. Frente a un vivo panorama global de circulación de obras, compañías y artistas, ocuparnos de un caso como el chileno -con tímidos pero incipientes y sólidos ejemplos- nos permite identificar algunos asuntos de interés en torno al fenómeno de la internacionalización. ${ }^{2}$ El teatro de exportación -como lo llamaremos de aquí en adelante- hace alusión a un tipo específico de teatro que es objeto de internacionalización, es decir, de circulación fuera de los límites nacionales. Se trata de un fenómeno relativamente reciente en Latinoamérica, poco sistemático y variable, razón por la que son escasas las reflexiones teóricas en torno al tema.

El término internacionalización se utilizaba, inicialmente, para abordar temas relacionados con el Derecho Internacional y el ejercicio de soberanía de un Estado en su territorio en favor de otros, específicamente, el sometimiento de espacios concretos como ciudades o territorios físicos a un régimen de administración internacional (Schriewer 21). Aplicado al ámbito de los estudios teatrales, el concepto designa una serie de variables que reúnen desde la organización de la producción interna de cada compañía, hasta el sistema de políticas culturales, económicas e institucionales que respaldan dicha producción tanto a nivel nacional como internacional.

Con la internacionalización se genera una red de implicación donde convergen la producción artística y los aparatos organizativos de las naciones involucradas en el marco de un plan de circulación de las obras. Un proyecto de internacionalización se construye, entonces, en torno al sistema de creación, producción y de difusión escénica, considerando la intervención y la conexión con el resto del mundo. La internacionalización es posible gracias a la convergencia de una producción teatral consistente, diversa y de calidad asentada en un territorio nacional, así como también a la gestión de los aparatos estatales y de las instituciones culturales involucradas, ya sean nacionales, internacionales, públicas y/o privadas.

Gracias a la estabilización político-social de los gobiernos, la implementación y mejoría de políticas públicas y de instituciones ocupadas en ello, la internacionalización de los objetos culturales nacionales - especialmente del teatro- ocupa un lugar importante en la visibilidad de las naciones debido a las ventajas que este fenómeno propicia: el contacto entre los países, ampliación de la circulación de las obras, el intercambio crítico y creativo entre los creadores, la difusión de las tendencias artísticas actuales de las naciones y la apertura de nuevas fuentes de ingresos económicos y recursos no monetarios para artistas y compañías.

2 Este estudio forma parte de una investigación más amplia que estudia el fenómeno de la exportación del teatro chileno en Italia. Véase Salvatori, Pía. Chile, Italia: 2006-2010. Estudio de un repertorio de exportación. Tesis. Università degli Studi di Firenze, 2016. 
Como se observa, este tema trasciende cuestiones estéticas, ampliándose hacia ámbitos organizativos, políticos y económicos. En esta ocasión, la reflexión que planteamos a lo largo de este artículo se concentrará preferentemente en el factor estético/ artístico, sin dejar de señalar las conexiones con factores extraestéticos que resulten más relevantes. La cuestión fundamental para este análisis, entonces, es reflexionar en torno a las características que delinean un repertorio de exportación que, a su vez, proyecta una imagen cultural del país de origen.

Se entiende aquí por repertorio un conjunto delimitado por cuestiones estéticas y extraestéticas precisas. Por una parte, entre los aspectos estéticos se reconocen los elementos vinculados con el objeto artístico en sí mismo, así como también las conexiones diacrónicas en relación con su contexto de producción. Por otra parte, entre las cuestiones extraestéticas se comprenden las políticas culturales vigentes del contexto de producción y de recepción, además de las dinámicas internas y de gestión de ambos espacios culturales, proyectos y financiamiento.

Para estudiar el fenómeno de la internacionalización de un repertorio teatral nacional se debe delimitar un corpus. En este artículo, el corpus corresponde al importante intercambio registrado entre teatro chileno e italiano, especialmente durante la XV edición del Festival Internacional Teatro a Mil (2008) y diversos festivales en Italia. La lejanía en términos de lengua y territorio y la inexistencia de un plan de internacionalización en las políticas culturales chilenas nos llevó a preguntarnos sobre las razones que motivaron la exportación de teatro chileno en dicho país.

Para identificar un repertorio de estudio fueron identificados algunos festivales italianos en el período que va entre 2006 y 2010, considerando la convocatoria nacional e internacional de artistas y de público, además de la antigüedad de funcionamiento que poseen. Distribuidos de norte a sur en la península, estos festivales son: Tramedautore (Milán, Lombardía), vie-Scena Contemporanea Festival (Módena, de Emilia Romaña), Napoli Festival (Nápoles, Campania), Festival dei Due Mondi (Spoleto, Umbria) y Rassegna Salento Negroamaro (Salento, Puglia). Las obras que componen el corpus de estudio son las siguientes: La tercera obra de la compañía La María; Cristo, excompañía Teatro de Chile; Neva de Guillermo Calderón, compañía Teatro en el Blanco; Rey planta de Manuela Infante, excompañía Teatro de Chile; Sin Sangre de Alessandro Baricco, El hombre que daba de beber a las mariposas, ambas de Teatro Cinema; Nijinsky o la mente asesinada de Héctor Noguera y Vicente Ruiz de la compañía La Desgracia Ajena; y por último, Monologs (laboratorio global de monólogos y vídeos).

La hipótesis de estudio es reconocer las coincidencias y/o divergencias desde un punto de vista estético de las obras que conforman este repertorio, para determinar, de ese modo, si en su conjunto presentan o no una imagen artística común que refiere a una forma de representar la cultura de procedencia. 


\section{Antecedentes}

El financiamiento de la cultura y, especialmente, de la producción teatral en Chile se realiza a través de entidades privadas y públicas. El sistema de financiamiento público se vincula preferentemente con el Consejo Nacional de la Cultura y las Artes (CNCA), entidad que gestiona los fondos estatales para distribuirlos entre personas naturales, personas jurídicas públicas o privadas, como es la Corporación Cultural Gabriela Mistral, la Corporación Matucana 100 o la Fundación Teatro a Mil (FITAM). Durante los años que abarca este estudio -2006 a 2010-, Chile elabora por primera vez un programa de políticas culturales con el cual se comienza a hablar de industrias culturales y circulación internacional. ${ }^{3}$

El repertorio analizado aquí, además, lo conforma una generación de jóvenes autorías -en su mayoría menores de 40 años-, egresados de una de las dos más importantes instituciones de formación en teatro, casi todos destacando por su trayectoria en el territorio nacional. Este dato generacional permite situar a dichos artistas en un contexto sociohistórico más amplio: una generación de posdictadura, que vive las consecuencias estéticas y temáticas dadas por la superación del llamado apagón cultural, vivido durante la dictadura militar en Chile.

Históricamente, la posdictadura refiere al proceso iniciado con la redemocratización oficial del país a partir de la asunción en 1990 del primer gobierno de la Concertación de Partidos por la Democracia, con Patricio Aylwin al mando. De acuerdo con Nelly Richard, el ambiente político y social de esta nueva democracia está caracterizado por una latente fase de amnesia en la historia nacional extendida hasta hoy: una que responde a la incapacidad de referir al pasado a través de un discurso común debido a que las políticas de gobierno se han concentrado en promover acciones basadas en consensos pasajeros. En este período no existió - ni existe en la actualidad- una aceptación de los acontecimientos históricos, así como tampoco una negación de los mismos. Para la autora, la "política de los consensos" ha arrastrado una paulatina cancelación de la memoria histórica nacional:

La "democracia de los acuerdos" que formula el gobierno chileno de la transición, señala el paso desde la política como antagonismo -la dramatización del conflicto regido por una mecánica de enfrentamiento- a la política como transacción, es decir, la fórmula del pacto y su tecnicismo de la negociación, que hace del consenso su garantía normativa [...]. ¿Qué desbordes buscó limitar el consenso, al pretender forzar la unanimidad de voces y conductas en torno a la racionalización formal y tecnificada del acuerdo? Desbordes de nombres [...] desbordes de cuerpos y de experiencias [...]; desbordes de memorias (Richard 27).

3 Previo a este documento emanado directamente del CNCA, tuvo lugar en el 1996 el "Encuentro de Políticas Públicas, Legislación y Propuestas Culturales" en el que fueron identificadas por primera vez -luego del gobierno militar- las necesidades de organización y legislación del sistema de producción cultural en el país. 
Los consensos buscaron neutralizar los discursos opuestos a través de una forma de pluralismo asentado en la no-contradicción. De ese modo, sin una confrontación de valores y de opinión, no se dieron las condiciones para una interpretación colectiva de la situación sociopolítica del país. No es casualidad que el eje memoria/identidad, sobre el que se funda el reconocimiento de los individuos por sí mismos en la comunidad, sea un tópico muy arraigado en la producción artística chilena actual. Su recurrencia expresa, precisamente, la tensión frente a la imposibilidad de nombrar la historia reciente, sus quiebres y abusos.

Por tanto, el consenso de la transición estaría cancelando sistemáticamente la memoria privada y la experiencia y, con ello, los desacuerdos frente a esta última. Volviendo a Richard, "conservamos la memoria de un pasado juzgado inconveniente por las guerras de interpretación y que se sigue desatando entre verdades y posiciones todavía sin ajustar" (29). El resultado es una suerte de dispersión de la verdad y de los acontecimientos, reduciendo también con ello la gravedad de los hechos y de sus significados para la comunidad.

El teatro de la generación de posdictadura se enfrenta a una sociedad aparentemente redemocratizada y fragmentada, y pone en acción diversas formas de representarla. JuanVillegas habla de una forma de despolitización del discurso teatral:

Ya sea por la posición del discurso político dominante, la Concertación Nacional -y su necesidad de eliminar las discrepancias entre sus integrantes frente al pasado inmediato- o por las tendencias mismas de la postmodernidad -énfasis en el objeto artístico, y no el mensaje-, los discursos teatrales de la hegemonía cultural tienden a silenciar la conflictividad social. Esto no significa la desaparición del cuestionamiento por algunos grupos. Esta tendencia se manifiesta tanto por ausencia como por la tendencia a deshistorizar la interpretación de la historia, a desnacionalizar algunos temas y la construcción de una imagen de lo nacional y lo popular que enfatizan lo folclórico tradicional (193).

La generación de posdictadura se extiende en una búsqueda más allá de lo nacional que, creemos, se mueve constantemente en una tensión entre una perspectiva globaluniversal y personal-local. Al deshistorizar la historia, el artista se concentra en la propia experiencia como individuo habitante de un mundo globalizado y en conflicto con una cultura altamente impersonal. De esta forma, aspectos como el testimonio, la focalización en la experiencia del escenario y la desestabilización de paradigmas -como el personaje o el espacio escénico- resultan ser los ejes -ampliamente ya reconocidos por los estudiosos del tema- sobre los que se funda gran parte del teatro contemporáneo actual. ${ }^{4}$

4 A propósito de lo anterior, abro un paréntesis para citar un sugerente estudio de Marco De Marinis, quien hizo en 1999 un balance del teatro europeo de fines de siglo luego de la revolución provocada por las vanguardias teatrales del siglo xx. Para el autor, la continua búsqueda de la superación de paradigmas, el autorreconocimiento y la relación entre el artista y el espacio real, permitieron construir un teatro fundado en el trabajo del actor desde su propio cuerpo concreto y presente, exaltando su presencia real y su dimensión no ficcional. 


\section{Hacia la construcción de un repertorio de exportación}

Ya se ha señalado que un repertorio es una forma de administración del patrimonio artístico que organiza los objetos artísticos con miras a su circulación internacional. Esto supone la identificación previa del contexto de recepción y la proyección de un núcleo de mercado al que va destinada la fruición.

En Italia existe una importante riqueza cultural. A nivel regional, esta multiplicidad se manifiesta en tradiciones, lenguas, artes e historia diversas, reflejadas en escenarios e imaginarios sociales altamente contrastantes. En el teatro, la diferencia cultural es apreciable en las diversas orientaciones que arrojan los festivales teatrales estudiados, ya que exhiben las necesidades y las tendencias identitarias regionales. Por ejemplo, el caso del Festival Rassegna Salento Negramaro, que en 2008 organizó la temporada dedicada a la historia de las culturas migrantes en Italia -en una zona considerada como una tierra de confín entre África y los países de la zona oriental y adriática de Europa- o bien, el Festival viE, centrado en las prácticas escénicas híbridas, las producciones contemporáneas y el teatro de experimentación, encuentro que se agrega además a las actividades de la región, conocidas por fomentar el teatro de investigación. También existe el Festival Tramedautore, concebido como un espacio para dar a conocer la nueva dramaturgia nacional e internacional; y el Napoli Teatro Festival, que acoge espectáculos de danza, teatro, performance y música, con énfasis en la dramaturgia contemporánea y la difusión de las nuevas escrituras y la dirección joven.

Con respecto al repertorio chileno, destaca la distancia lingüística existente con Italia, así como también la conexión generacional entre los creadores de las obras. Si bien estas en su mayoría fueron producidas en Chile, obtuvieron el financiamiento de instituciones europeas privadas dedicadas a la difusión de las artes escénicas para su internacionalización. Dichas instituciones actúan en conjunto acordando presentaciones en otras ciudades y países, lo que se traduce, entre otras cosas, en una reducción de costos. No se reconoce la presencia constante de alguna institución chilena que fomente la internacionalización de manera sistemática. En este sentido, el CNCA -y el FONDART - figura como una instancia de financiamiento de la producción en territorio nacional y no de fomento a la circulación. A continuación, se presenta un resumen focalizado en el análisis de cada obra componente del repertorio.

\section{La tercera obra, de María José Von Hummel y Alexis Moreno, compañía La María}

Esta compañía es liderada por egresados de la Universidad de Chile y, desde su creación en 1999, se ha adjudicado diversos proyectos entre los que destaca el FONDART de Excelencia con la obra La trilogía pública de 2005. En Italia se presentó durante la 
segunda edición del vie-Scena Contemporanea Festival de Módena, llevado a cabo en junio del 2006. La gira fue financiada por la gestión de la organización de este festival y el Festival de Bayonne en Francia. Luego de Módena, la obra se presentó en el Teatro Nuovo de Nápoles. La tercera obra es una creación colectiva, tercer componente de La trilogía pública compuesta por Superhéroes (Criminales nostálgicos) y Numancia, escritas por Alexis Moreno y estrenadas respectivamente en marzo, julio y octubre de 2005.

En su texto escrito se lee: "ejercicio teatral" (1). Ello sugiere, entre otras directrices, la apertura de esta obra a la improvisación y al carácter matriz del texto teatral. Su estructura está basada en una concatenación de unidades escénicas independientes, numeradas y subtituladas en las que parece no primar un orden fijo, es decir, cada escena conforma una unidad temática y estructural en sí misma. La mayor parte de las unidades escénicas y los parlamentos parecen ser más bien la transcripción de una conversación no estructurada e interrumpida por momentos lúdicos de representación ficcional de otras microhistorias. En este sentido, la historia se estructura de forma abierta y rizomática, facilitando la digresión en otras situaciones/escenas adyacentes a la principal.

La organización global de la historia está dada por el esquema: escena enmarcante/enmarcada, es decir, estructuras que contienen otras. La escena enmarcante se caracteriza por su dimensión real y cotidiana, mientras que las escenas enmarcadas, por su dimensión ficcional. El plano de lo real es una suerte de texto argumental y comentario crítico de las situaciones recreadas; las escenas enmarcadas son historias ficcionales desarrolladas a través de canciones, entrevistas, conversaciones, acciones con o sin texto y fragmentos extraídos de la obra Terror y miserias del tercer Reich de Bertolt Brecht. Las escenas ficcionales ponen en acción la revisión crítica de innumerables situaciones irresueltas del Chile de la posdictadura. De esta manera, la obra desarrolla un fuerte contraste entre la dimensión real y ficcional, fenómeno que provoca constantemente el distanciamiento del espectador.

Camila Van Diest y Fernanda Carvajal estudian La trilogía pública valorizando la propuesta escenográfica total como metáfora de una experiencia histórica nacional. Dicha experiencia -fragmentaria, parcial y rebelde- resulta problemática para efectos de un poder totalitario. De allí que uno de los temas recurrentes -la crisis de la identidad-aparezca como "resultado de la aplicación de un poder hegemónico y central, constructor de totalidades sin exclusiones, aplicado básicamente como un modo único de leer lo real (y lo histórico) y creando con ello individuos convenientes a dicho modelo" (Carvajal y Van Diest 100). Lo público se configura como territorio de lucha por la veracidad de los discursos históricos y, a su vez, determinan el modo en que cada individuo valoriza su contexto. Esto es abordado en las escenas enmarcadas que componen la obra, específicamente a través de situaciones que profundizan cuestiones en torno a la identidad, el terror y la desconfianza que subyace en los círculos sociales. La búsqueda de rasgos identitarios de la colectividad -llevada a cabo en la 
dramaturgia del texto, las acciones, objetos y escenografía- es un tema recurrente que tiene sus raíces en un pasado violento y confuso.

En el plano estético, el montaje destaca por su composición transmedial. ${ }^{5} \mathrm{La}$ puesta en escena se construye en la conjunción de proyectores, cámaras, radio, grabadoras, pantallas, música y escenografía. A través de estos medios se configuran escenas completas, añadidas a la historia matriz por los actores. Ejemplo de ello es la escena de apertura: allí aparece proyectada en un video la conversación inicial de la obra al mismo tiempo en que los actores la ejecutan en el escenario. El video se repite hasta que todo el público entra en sala: “TRANSCRIPCIÓN VIDEO: Hablemos del título / Eso, hablemos del título / ¿Cómo le podemos poner? /Sí, cómo le podemos poner /Alexandra / ¿Qué título le pondríamos a la obra?” (1).

Durante el resto de la obra, el diálogo se produce en manera casual y aparentemente cotidiana, quitando cualquier efecto de artificialidad o de ensayo a la representación. Con estas operaciones, creemos que el montaje apunta a su objetivo principal: plantearse como un espacio de investigación y observación del entorno, impidiendo al espectador ensimismarse completamente con lo que ve, provocando así una reflexión crítica.

\section{Cristo, creación colectiva de la excompañía Teatro de Chile}

Conformada por actores y diseñadores de la Universidad de Chile, bajo la dirección de Manuela Infante, la compañía se mantuvo activa desde 2001 hasta 2016. La obra en cuestión fue realizada en dos etapas: la primera en Ámsterdam, a principios del 2007, que culmina con la presentación de un work in progress. La segunda fue el resultado de una creación colectiva realizada en Santiago de Chile y estrenada durante 2008. En ese mismo año, fue presentada en el Festival Dei Due Mondi de Spoleto en Italia.

La historia se desarrolla en torno a un grupo de actores reunidos con el fin de investigar sobre la leyenda del Cristo de Curimón. Dos espacios y dos tiempos intervienen en esta historia: uno está configurado por la escena titulada "Los viejos" con la cual abre la obra y en la que se muestra a un grupo de ancianos mientras ensayan la representación de la última cena. El otro momento, titulado "Disertación", se desarrolla con la escenificación, configurada por los actores que investigan en torno a

5 Este concepto proveniente de las teorías de la comunicación, a través del cual se redimensiona la influencia operada por los diversos procesos de hibridación en el teatro contemporáneo. Descrito en primera instancia por Henry Jenkins (2007), alude a la cualidad narrativa de los diversos dispositivos que configuran una narración. Aplicado al teatro, lo transmedial se traduce como el diálogo de diferentes códigos estéticos -también llamados textos mediales- presentes en una obra. Con este término se expresa también la complejidad y la autonomía con que los diversos medios intervienen en la construcción del objeto; el uso de diversos soportes implica también varios lenguajes y sistemas significantes (ver De Toro). Si bien es cierto, el concepto es usado preferentemente para estudiar los productos artísticos desde el cruce entre las diversas plataformas comunicativas mediales -cine, TV, cómic, vídeo juegos, música, literatura- y en un contexto cultural preciso, es posible estudiar ciertas prácticas teatrales contemporáneas a la luz de algunos fenómenos, aún tímidos, que implican una condición transmedial. 
la historia del Cristo de Curimón, de la escena de "Los viejos". La lógica estructural de la historia está dada por la presencia de una escena enmarcante, "Disertación", sostenida por los actores de la compañía, junto a otras enmarcadas que corresponden a las historias ficcionales. A propósito, señala Infante:

Intentando dar una respuesta a quién era Cristo, nos dimos cuenta de que a lo único que podíamos acceder era a representaciones de Cristo. En otras palabras, esta idea, imagen o concepto de lo que llamábamos Cristo, y que antes nos parecía estable, autocontenido y consciente, parecía haberse dispersado bajo una mirada más inquisitiva, parecía haberse fragmentado en miles de otras imágenes y conceptos ¿sería Cristo una cadena interminable de figuras, palabras, cuadros, canciones, una detrás de otra, superpuestas? (Cristo 10).

En estas premisas emergen los diversos niveles de significado sobre los que se construirá la obra, es decir, el espacio autorreferencial del escenario que denota lo que realmente acontece con los actores y personajes y, a su vez, la dimensión ficcional que permea el acontecimiento teatral mismo y entra en fuerte contraste con la primera.

La escena general se despliega como una batalla de signos, un zapping continuo de imágenes y diversos niveles de enunciación donde se contraponen continuamente la dimensión ficcional y la real. La obra profundiza sistemáticamente en la manera en que las historias devienen representaciones y, en definitiva, construcciones de lenguaje. Esta lógica lleva a concentrar el conflicto en la tensión entre representación y teatro, cuestionando la veracidad del acontecimiento teatral.

La transmedialidad, importante característica de este montaje, sigue la premisa anterior. Los medios superponen los planos reales y ficcionales, junto con alternar las cualidades de originalidad, realidad y verdad mediante la postproducción. Narrativamente, lo transmedial permite multiplicar y dar simultaneidad a los espacios y los tiempos de la escena, en decir, recortar, repetir, concatenar las diversas escenas, generando copias de copias que construyen el universo hiperreal del montaje. ${ }^{6}$ Todo esto con la finalidad de discutir, de cuestionar y reorganizar la frágil consistencia de las historias tradicionales.

La escenografía también sugiere las ideas anteriores: formada por muchas cajas de cartón dispuestas en el espacio, movidas y usadas para fijar el gesto de los cuerpos. El cartón remite a la idea del reciclaje, del archivo, de lo básico y lo simple, especialmente también, la frágil consistencia de la tradición.

6 El concepto de hiperrealidad descrito por Jean Baudrillard se explica en correlato a la noción de simulacro definida por el mismo autor y ya descrita precedentemente por Georges Bataille, Pierre Klossowski, Gilles Deleuze, entre otros. El simulacro se instala en la superficie, coincidiendo y suplantando lo real; no designa una imitación o un doble de algo preexistente, ni evoca ningún original, sino que lleva a cabo un proceso continuo de destrucción de la realidad y de vaciamiento. La simulación pone en duda la realidad y la sobrepasa; en este sentido, se plantea como un original en sí mismo porque está presente simulando la realidad. A través del simulacro hiperreal todo se hace extremadamente visible: "la simulación no corresponde a un territorio, a una referencia, a una sustancia, sino que es la generación por los modelos de algo real sin origen ni realidad: lo hiperreal” (9). 


\section{Neva, de Guillermo Calderón, compañía Teatro en el Blanco}

Esta compañía se formó en el 2006 con integrantes egresados de la Universidad de Chile. Hasta la fecha ha presentado diversos trabajos en Chile y el extranjero bajo la dirección y dramaturgia de Guillermo Calderón. Neva fue estrenada en 2008 en los festivales viE, Scena contemporanea (Módena) y Tramedautore, en este último presentada como una lectura escénica.

La historia de Neva se sitúa en Rusia en el año 1905 con tres actores en escena -Olga (la viuda de Chejov), Masha y Aleko- reunidos en una sala de teatro con el objetivo de ensayar algunas partes de El jardín de los cerezos de Chejov. Paralelamente, se están preparando manifestaciones en la ciudad, impulsadas por una gran revolución.

Más que la acción física, el rol protagónico de la obra lo asume el discurso lingüístico, lo dicho, donde coexisten dos planos enunciativos estructurados al modo de "teatro en el teatro". El primero lo constituye la historia desarrollada entre Masha, Aleko y Olga, mientras que el segundo, el texto recitado del Jardín de los cerezos. La alternancia entre ambos planos genera el extrañamiento y distanciamiento de la escena, especialmente cuando las citas del Jardín... acompañan la formulación de un discurso crítico metateatral en torno a la creación y el valor del teatro en el contexto sociopolítico de ese momento.

Con este recurso se presenta la vida de los personajes como una constante citación de "algo ya dicho". La historia es planteada, de ese modo, en tanto una reiteración de citas que llaman la ficción y que, a su vez, ocultan a los personajes de un duro ambiente exterior. La repetición de un texto completamente despojado de su capacidad performativa se vuelve metáfora de la inactividad de los personajes frente a la situación contingente del afuera.

En la obra, el teatro constituye un lugar de aislamiento voluntario, de falsedad y simulación, carente de un vínculo con la historia, alejado de la colectividad y de la tradición, incluso privado de ética y funcionalidad con respecto a su entorno sociopolítico, es decir, aparece como un lugar sin memoria. El actor narcisista es un ser insatisfecho e incapaz de comprometerse con su realidad; vive una y otra vez una existencia posible de ser ensayada incansablemente:

Masha: Olga, va a haber una revolución y va a ser tan linda. La gente va a cantar en las calles y después va a morir [...]. El teatro se hizo para gentes como ustedes, para poderlos quemar ¿cuánto rato se puede hablar de amor? [...] Afuera hay un domingo sangriento, la gente se está muriendo de hambre en la calle y tú quieres hacer una obra de teatro (Calderón 332).

La atmósfera que predomina en la escena es de carácter íntimo y minimalista, los actores parecen escondidos y suspendidos en un tiempo sin límites. En el escenario, solo hay una luz emitida por un calefactor al centro. Estos pocos elementos configuran una "estética del despojo" (Oyarzún 304), que se aleja de la espectacularidad para concentrarse en las tensiones del actor y su trabajo. 


\section{Rey planta, de Manuela Infante}

La obra fue presentada como una mise en espace, traducida al italiano en 2008, durante el festival de dramaturgia contemporánea Tramedautore de Milán. Se incluye en el corpus de este artículo, pues antes de que fuera presentada, la directora de dicho festival nos reveló que luego de asistir a su puesta en escena en Santiago propuso traducirla y llevarla al festival. El texto de esta obra fue traducido y publicado en italiano junto a Neva de Guillermo Calderón, bajo el título Re! Giovani voci della drammaturgia cilena.

Rey Planta es un monólogo inspirado en hechos reales ocurridos en Nepal durante el 2001: un rey mató a su familia, luego intentó un suicidio sin éxito que lo dejó paralizado por el resto de sus días. No es la primera vez que Infante escribe inspirada en personajes históricos - ha escrito ya sobre Prat, Juana y Cristo, obras homónimamente tituladas-, probando cuestionar los contenidos simbólicos que surgen en el imaginario colectivo de una comunidad.

A diferencia de Cristo, este monólogo es un texto completo y acabado, y no la revelación de un proceso artístico investigativo. La historia de la obra se desarrolla cronológicamente - día, atardecer, noche y amanecer- a través del manejo de luces, sonidos y proyecciones. En el escenario, un cuerpo inmóvil y paralizado yace sobre un trono. Del personaje se conocerán sus más recónditos pensamientos a través del texto recitado en off por una voz femenina.

La obra se construye mediante la superposición de dos planos discursivos diversos, el de la historia del rey y el del actor junto a sus técnicos, presentados en el espacio de la siguiente forma: "un rey sentado en un trono. El trono al interior de una vitrina. La vitrina al interior de un museo. El museo es el palacio. El rey está en estado vegetal. Solo puede mover los ojos" (Infante, Rey 238). En esta didascalia de apertura se describe el primer plano discursivo: el espacio dramático de la historia, el palacio que es, a su vez, un museo. Casi al cierre de la obra se descubre el segundo plano discursivo con la irrupción de un último personaje - un técnico- que ingresa para arreglar el cuerpo del rey. De ese modo, su intervención crea el segundo nivel discursivo, el del teatro. La didascalia que cierra la obra recita: "comienza tímidamente a moverse, sonido, el bufón lo golpea, el rey se cae, el bufón lo vuelve a la posición original, alguien grita ¡estamos listos, se abre la sala!” (257). Esta irrupción culmina con el espacio dramático de la historia ficcional, resaltando el carácter artificial del teatro. A través de sutiles mecanismos, la obra sugiere su propio proceso de producción y, con ello, su posición con respecto a los temas que se exponen en la historia. Dicho mecanismo quiebra el ensimismamiento del espectador y lo obliga a distanciarse de la ficción.

La posición del personaje con respecto a la configuración de los espacios y los niveles discursivos es compleja. El rey inmóvil en su palacio, completamente impedido para expresar sus deseos, ejerce un poder que se propaga independiente de sus posibilidades físicas, poder que se ejerce y completa en su autoexhibición. La sola presencia del rey basta para gobernar, y de ello es signo el espacio de la vitrina del 
museo. El cuerpo inmovilizado e intocable del rey, por tanto, es metáfora de una forma invisible y aplastante de autoridad que, si bien puede ejercer el poder solo con estar presente, no le pertenece. El cuerpo, de ese modo, aparece como signo espectacular de la soberanía oculta y, al mismo tiempo, de su inexistencia:

El incesante monólogo de este rey en estado vegetal con su sola presencia estática nos invita a pensar en torno a las paradojas del poder, ese poder porque sí, porque se hereda, absoluto y divino. Un poder que es una tentativa de codificar y demarcar los cuerpos, que evidencia que, entre todos los individuos, como sostiene Foucault, pasan por relaciones de poder que no son la proyección pura y simple del gran poder del soberano sobre los individuos, sino más bien el suelo movedizo y concreto sobre el que ese poder se incardina (Jeftanovic 235).

La instalación ficcional del poder se constituye en un gesto crítico que toca un lugar común ya advertido hasta ahora en el estudio del corpus: la crisis de la representación. Develar el funcionamiento del simulacro teatral conforma una analogía con respecto a la operación de descubrimiento del simulacro de lo cotidiano. La representación no está entendida aquí como un concepto puramente teatral, sino que se extiende a la contingencia política y social a situaciones de carácter actual, por ejemplo, como lo ocurrido en Chile con el dictador Augusto Pinochet y la imposibilidad de las autoridades y sus estructuras para hacer justicia. La vitrina es una forma de distanciamiento que busca hacer visibles los conflictos irresueltos de la sociedad chilena. En este sentido, la obra hace evidentes comportamientos y convenciones cotidianas de las que espectador y rey devienen voyeurs de sí mismos.

En el plano estético/formal, el monólogo es minimalista y la escenificación no recurre a grandes instalaciones. Basta una pantalla blanca en el fondo del escenario para acompañar con imágenes y colores los estados emocionales del personaje, figurando a su vez como testigo amplificador de lo que acontece.

\section{Sin Sangre, de Alessandro Baricco, adaptación de la compañía Teatro Cinema}

La compañía Teatro Cinema inicia su historia como agrupación en 2006 con esta obra, la primera parte de una trilogía. A la fecha, ya fueron presentadas al público las otras dos partes: El hombre que daba de beber a las mariposas (2010) e Historia de amor (2014). El grupo de actores que la conforma nace durante el año 1987 como "Los que No Estaban Muertos", y posteriormente conformaron La Troppa, agrupación que desarrolló algunos famosos espectáculos todavía vigentes. En Italia, Sin sangre fue presentada en el Festival dei Due Mondi de Spoleto y el Festival di Napoli y Rassegna Salento Negroamaro durante el 2008. El espectáculo ha sido coproducido por FITAM, Le Manege Mons Centre Dramatique (Bélgica), con el auspicio de fONDART. 
La obra está basada en la novela homónima de Alessandro Baricco (Senza sangue), historia que se desarrolla en torno a diez personajes que reconstruyen el relato de un asesinato y la venganza de la protagonista. El tiempo de la historia se presenta en dos formas: el primer acto consiste en un racconto de las memorias de la protagonista sobre el asesinato del padre y del hermano; el segundo se instala en el presente narrado por la protagonista y uno de los agresores que le concedió la vida. Si bien el tiempo de la historia se cierra en el mismo lugar en que se inició, durante su desarrollo confluyen una multiplicidad de espacios y de tiempos reunidos mediante diversas técnicas narrativas: repetición, flash back, racconto, saltos al futuro, entre otros.

Los protagonistas reconstruyen un pasado del cual se conocen solo los fragmentos. En tanto metáfora de una restitución y reconstrucción, la historia pasa fundamentalmente por la tríada venganza-violencia-amor. Cuando la sucesión de actos vengativos llega a su clímax -punto aparentemente catártico para los protagonistas-, el ascenso se interrumpe abruptamente por acción del amor, cortando la sucesión de actos trágicos, permitiendo así el perdón y la reconciliación.

La puesta en escena destaca por su gran espectacularidad. El escenario está compuesto por dos pantallas blancas en las que se proyecta una secuencia de imágenes entrelazadas con el movimiento de los actores, la música sintetizada y las luces. Estos dispositivos generan un efecto cercano a la estética cinematográfica y posibilitan la perspectiva omnisciente de la narración. Lo proyectado en las pantallas emerge como un "ojo invisible", trasladado hacia cualquier tiempo y espacio, revelando el punto de vista de los personajes y los saltos espacio-temporales. El narrador panóptico guía al espectador y pone la historia en una permanente visibilidad, estableciendo con ello su universo referencial.

Sin sangre es una propuesta híbrida y transmedial, ya que además de propiciar la comunión de diversos lenguajes, permite la coexistencia de diversos medios cuya función narrativa interviene de manera no jerárquica aportando, junto al actor, elementos a la narración global. Lo transmedial interviene, también, para presentar detalles, remarcar y especificar acontecimientos o elementos de las escenas -por ejemplo, los pasos de los personajes, evidenciar las armas o los objetos en el espacio, ampliar los gestos físicos-, para enriquecer los estados emocionales de los personajes y/o las atmósferas de las acciones, para facilitar los cambios de escena y/o actos, así como también el cruce de perspectivas narrativas omnisciente, protagonista, entre otras.

La transmedialidad es también verificable en el texto escrito en tanto forma potencial de tridimensionalidad. Este se caracteriza por seguir una estructura rígida y sistemática: cada escena se encuentra numerada, subtitulada, con indicaciones de música y setting donde destaca la recurrencia de la nomenclatura cinematográfica para referir en términos técnicos a lo que sucede con las proyecciones o con los personajes -flashback, flash forward, elipsis, dolly, slow motion, tilt up, paneo, zoom back, close up-. Todo lo anterior implica un saber específico previo por parte del lector. Otro rasgo observable de transmedialidad aparece con la adaptación del texto narrativo 
desde una lengua extranjera al español y su codificación en formato cinematográfico. Tal como señala un estudio de Espinoza y Miranda en torno a este y otros espectáculos de la generación, dichos procedimientos constituyen ejemplos de operaciones transculturales, transtextuales y transdisciplinarias (98), fenómenos ya recurrentes en la escena teatral chilena contemporánea.

\section{El hombre que daba de beber a las mariposas, creación colectiva de la compañía Teatro Cinema}

Esta obra consiste en la segunda parte de una trilogía realizada en coproducción con Scène Nationale de Sète et du Bassi de Thau (Francia), fitam (Chile), Centre Dramatique Le Manège-Mons (Bélgica), Napoli Teatro Festival (Italia), Festival Internacional de Edimburgo (Escocia) y el auspicio del CNCA y del Office National de Diffusion Artistique (Francia). Para su presentación en Nápoles figuran también otros colaboradores como RAI, el Centro de Producción de Nápoles y el Programa Iberescena.

En esta segunda parte de la trilogía se retoma el amor como eje conductor de la obra. El amor en sus diversas manifestaciones -familiar, de pareja, amor épico, entre otros-, entendido como un elemento intrínseco a los seres humanos, capaz de trascender el tiempo y el espacio. Mediante un personaje (Filippo) y un elemento (la mariposa) se entretejen todas las historias.

La progresión de las imágenes es rápida, incluso vertiginosa: el espectador es bombardeado por su continua sucesión, donde se alternan diversas historias y focalizaciones narrativas. La obra se inicia y cierra en un mismo punto: Filippo, a punto de sufrir un paro cardíaco, se prepara para cumplir por última vez su labor de alimentar a las mariposas. El cruce entre las historias va dando la progresión a la obra cuya disposición temporal no es lineal.

Esta obra define su estética híbrida mediante la comunión de los lenguajes de las proyecciones en 2D, animación y teatro. En comparación con la primera parte de la trilogía, la transmedialidad interviene aquí de manera aún más radical que la anterior: los dispositivos escénicos asumen gran parte de la narración, cuestión que se refleja en el discurso didascálico del texto como lo demuestra la Obertura: "1.P1 Una mariposa dibuja a Filippo / Vídeo 1- P1: Mariposa volando dibujando a Filippo / La P1 está en azul, luego muta a blanco. Una mariposa entra en la pantalla volando y dibuja a Filippo, el hombre que daba de beber a las mariposas que va corriendo de frente. La mariposa desaparece bajo el dibujo. La imagen se funde con Filippo real que corre por un pasillo" (Pizarro 1). El predominio de la transmedialidad, en palabras del director, busca este efecto:

En Sin Sangre experimentamos con el teatro y el cine negro, ese cine de los años 40 y 50. Con El hombre que daba de beber a las mariposas las relaciones entre el teatro y la animación 2D, y en Historia de amor trabajamos con la relación del teatro y el cómic. Cuando empezamos a trabajar en esto, la premisa de Teatro 
Cinema fue lograr que el actor en vivo pueda viajar en el tiempo y el espacio de forma instantánea, tal y como ocurre en el cine y la literatura. Entonces empezamos a desarrollar un lenguaje que nos permitiera cambiar en un segundo, con el actor en escena, toda la escenografía al lugar que queramos: desde una calle a un departamento o a una cárcel. Trabajamos en la estructura del corte y la unión. Digámoslo así, nosotros hacemos la edición que se hace con las películas, pero en vivo (Zagal).

El trabajo de postproducción es una etapa importante en la creación, ya que la mayor parte del material usado en la obra es fruto de la manipulación del original y de la fuerte comunión entre los lenguajes del cine y del teatro. La imagen intervenida se integra a la del cuerpo del actor en manera que el cuerpo físico pierde su dimensión concreta para adquirir una dimensión virtual. El sofisticado soporte transmedial configurado por Teatro Cinema crea diversas realidades en el escenario sin la necesaria mediación del cuerpo presente.

A pesar de la importante incidencia de lo transmedial el proceso de teatralidad no se ve alterado, es más, el montaje ahonda precisamente en la búsqueda del no realismo, la ilusión y la magia del teatro, reforzando con esto la dimensión ficcional de la obra. La cuarta pared teatral se vuelve una pantalla cinematográfica. El artificio, el truco visual envuelven al espectador en el simulacro del espectáculo. Sin embargo, paradójicamente, la espectacularidad puede llevar al distanciamiento del espectador, ya que percibe la ausencia de la organicidad del actor dado que parece ser más real en una pantalla que en el escenario.

\section{Nijinsky o la mente asesinada, de Héctor Noguera y Vicente Ruiz}

En 2003, dos artistas chilenos crearon una performance en torno a la vida del reconocido bailarín ruso Nijinsky (1890-1950), considerado el padre de la danza moderna. La obra fue retomada y presentada en Italia en 2008 para la Rassegna Salento Negroamaro y el Istituto Italo-Latino Americano (IILA) en Roma. Ambos artistas chilenos cuentan con una larga trayectoria en la escena nacional. Héctor Noguera (1937), destacado actor de teatro y de televisión, es quien interpreta la obra; y Vicente Ruiz (1958), bailarín y coreógrafo, es el director. En base a algunos principios del método de Ruiz -como la danza en tiempo real-, el montaje indaga en la capacidad performativa de los lenguajes de esta disciplina buscando desarrollar una acción coreográfica en tiempo real junto al progreso de un texto dramático.

La historia que presenta esta obra se sumerge en la última etapa de la vida del bailarín, internado en un hospital psiquiátrico. Explora los meandros de una mente poblada por los fantasmas del pasado que emergen a través de los lenguajes de la danza y la recitación. En un intenso monólogo, el protagonista aislado del mundo y 
encerrado en su habitación reconstruye los recuerdos y convoca algunos momentos decisivos de su vida artística.

La danza en escena se estructura en secuencias de movimiento que van desde el Butoh, al ballet y a la técnica Graham. De ese modo, el personaje crea, investiga e reinventa el movimiento durante la escena. El monólogo se construye básicamente en la progresión de la locura del personaje: imágenes y acciones delirantes convergen hasta el desenlace, momento de mayor tensión dramática.

El texto escrito está dividido en tres series, a su vez, subdivididas en escenas numeradas más o menos independientes del texto, característica que también está presente en el discurso didascálico que, al contrario de preservar el sustrato narrativo del texto dramático, parece representar una parte de la mente disociada del personaje: "Serie I: 1-Nijinsky con la frente apoyada en un muro o un mueble, sentado en una silla. Tentación de risa. Mira un partido de tenis. Hilaridad con la audiencia. Todo el mundo debe reírse / Serie II: 1- En el interior de la mente de Nijinsky. Monta la coreografía de La consagración de la primavera" (Noguera y Ruiz 1). A nivel de estructura dramática y textual, la obra es fragmentaria, alegoría de una memoria también fragmentada. La puesta en escena se caracteriza por la primacía de la dimensión física, por la expresión corporal y la progresión de la emotividad del personaje, más que por desarrollo de un texto dramático o de una historia.

\section{Monologs (laboratorio global de monólogos y vídeos), diversas autorías, compañía La Desgracia Ajena}

Este proyecto, dirigido por Pedro Sepúlveda, fue creado y presentado por primera vez el año 2006 en Santiago. La propuesta comprendió la instalación de nueve monólogos que operan en forma simultánea, situados en diversos puntos de la ciudad, los cuales constituyen un encuentro entre los lenguajes audiovisuales y teatrales a través de una instalación urbana.

En Italia el proyecto se presentó en el festival italiano Rassegna Salento Negroamaro (Lecce), para la edición 2008, titulada Territorios. En ese montaje fue pensado como una contribución a la ciudad dada la carencia de espacios dedicados al teatro. ${ }^{7}$ Los monólogos presentados fueron: Bosque, por Matías Feldman (Argentina); Mujer Promiscua, por Ximena Escalante (México); Johnny Deep, por Alejandro Moreno

\footnotetext{
7 "Nato dalla constatazione di un gruppo di artisti della mancanza di spazio nei luoghi ufficialmente deputati allespressione artistica, sia individuale che di gruppo. Questa percezione si è trasformata in una proposta di intervento urbano, che si concretizza con un dispositivo scenico che accoglie l'incontro fra gli attori e la gente che abitualmente popola gli spazi pubblici”, "Nacido de la constatación hecha por un grupo de artistas de la falta de lugares oficialmente dedicados a la expresión artística, tanto individual como de grupo. Esta percepción se transformó en una propuesta de intervención urbana que se concreta través de un dispositivo escénico que acoge el encuentro entre actores y la gente que cotidianamente recorre los espacios públicos" (Programma della Rassegna delle Culture Migranti 21, traducción propia).
} 
(Chile); 8:45 Heaven, por Luis Mario Moncada (México); Anhelos de color blanco, por Natalia Matzner (Chile) y Salomé, Bonus track.

Una de estas direcciones comunes para aunar las diversas propuestas estéticas fue la instalación del dispositivo escénico de una caja, como contenedor de historias. En su interior convergen una serie de imágenes sonoras y visivas que completan la interpretación. La caja funciona como un organismo autónomo y productor de información donde confluyen todos los monólogos en juego. La caja es alegoría de la pantalla, presencia omnipresente de la vida cotidiana moderna capaz de definir las formas en que se establece el contacto entre las personas. La organicidad del cuerpo del actor contrasta con la virtualidad de la pantalla y de los dispositivos audiovisuales que intervienen en cada monólogo.

La continua sucesión de los monólogos dentro de cada caja subvierte la idea del teatro y la performance como acto único. El actor aislado es puesto en vitrina y limitado a su presencia virtual. La instalación urbana se presenta al espectador como un zapping televisivo, en el cual el receptor ideal, selectivo y nómada puede entrar y salir del montaje, componiendo de ese modo su propio recorrido. Al respecto, Espinoza y Miranda señalan: "el espectador espontáneo o el que va a presenciar a sabiendas el espectáculo, se convierte en un usuario televisivo, al que se le ofrece un permanente zapping textual, sea de las obras presentadas, o de los vídeos como cápsulas de información o de la intervención del espacio urbano de la performance" (70).

El proyecto fue concebido como una forma de democratización del teatro capaz de atraer la atención de diversos públicos, y en donde el espectador-transeúnte goza de fácil y gratuito acceso. Cada monólogo implicó el trabajo de un actor, un director junto a diverso material audiovisual -documentales, entrevistas, registraciones de ensayos, videoclips, imágenes-. Por este motivo puede ser definida como una propuesta de texto dramático, híbrida y transmedial. Todas las subinstalaciones se sirven de una escenografía funcional -caja, paneles, televisores, proyectores, micrófonos, radios, grabadoras, computadoras, sillas, telas, entre otros- que delimita el espacio de la escena. La transmedialidad establece y potencia los espacios individuales, introduce elementos narrativos y signos a la acción; permite también intervenir y resignificar el espacio cotidiano, contribuyendo con la teatralidad de la intervención.

La tecnología produce y conduce, también, una determinada tipología de relaciones humanas. La instalación extrae el teatro del mismo teatro, otorga a un espacio cotidiano y no convencional un nuevo significado mediante una escenografía funcional que está en directa relación con los personajes de los monólogos. $\mathrm{Al}$ mismo tiempo, explora las formas de intervenir y romper con la escena urbana a través de la dimensión concreta y física del evento teatral. Monologs teje en torno a la ciudad un simulacro ficcional y extracotidiano, instala un objeto-prótesis siempre disponible al espectador, en el cual se desarrolla una escena paralela al mundo cotidiano: cada pantalla ofrece un close-up parcial de un universo independiente que irrumpe en la urbe. 
La condición de evento en continua renovación y la posibilidad de interacción inmediata con el público de la propuesta le donan espontaneidad y rapidez. De la misma manera, la situación específica en la que se instala la performance permite conectar el trabajo de los creadores con un territorio cultural y físicamente diverso al de ellos mismos.

\section{Conclusiones}

Lo que se ha denominado como teatro de exportación aparece estrechamente ligado a la implementación de ciertas políticas culturales, a la gestión de entidades públicas y privadas, nacionales e internacionales y, especialmente, a una serie de rasgos estéticos comunes entre las obras. Ha sido posible reconocer que, a nivel estético y formal, estas obras destacan por una hibridez construida en el cruce de lenguajes y de medios diversos. La cultura digital - medios web, video y sonido digital, video instalación, proyecciones digitales, entre otras- dialoga con los cuerpos en escena, el texto, la escenografía y el resto de los elementos que las componen.

El modo en que inciden las tecnologías en estas obras dio origen a productos transmediales, en la medida en que los diversos códigos estéticos reunidos interaccionan entre sí como actantes autónomos para agregar otras tramas narrativas a la escena principal -ejemplos de ello son los montajes de Teatro Cinema, La tercera obra o Cristo-. La transmedialidad posibilitó escenas rizomáticas y pluridireccionales. Por lo mismo, las estructuras narrativas recurrentes en este repertorio fueron: la superposición de planos discursivos y espacio-temporales, la fragmentación y la repetición.

La influencia de la tecnología tendió a configurar dramaturgias espectaculares asentadas en lo visual. En los casos más radicales, esta influencia implicó la desnaturalización de la presencia orgánica del actor, como ocurre, por ejemplo, en El hombre que daba de beber a las mariposas, donde los cuerpos y su dimensión orgánica fueron más bien absorbidos por los dispositivos tecnológicos en escena. Por otra parte, también se buscó alejar la tecnología de una funcionalidad ficcional con el fin de acercarla a sus posibilidades instrumentales de investigación y cercanía a lo real en coherencia con los temas tratados en cada obra. Esto puede verse, especialmente, en Cristo y La tercera obra. Por último, también existieron espectáculos en los que prácticamente no se emplean recursos tecnológicos - como Neva- y otros que los utilizan, pero de modo secundario o auxiliar, como el Rey Planta y Nijinsky o la mente asesinada.

La desaparición literal de discursos históricos nacionales, junto con la recurrencia de temas cuyo interés se considera universal -como el amor, la violencia, el poder, la locura, entre otros- evidencia un cambio en la forma de referir a la memoria colectiva de una comunidad. Dicha memoria ya no está ligada estrictamente a los acontecimientos históricos nacionales, más bien aparece abierta a conexiones metafóricas con otras historias que, de alguna manera, resultan más accesibles para un espectador proveniente de otro contexto cultural. 
En el leiv motiv de la reconstrucción -tema recurrente en el conjunto de obrasse refleja lo impreso por una política de consensos en el inconsciente colectivo de la generación de posdictadura. Las formas testimoniales y autobiográficas emergen como espacios de resistencia frente a la indeterminación de una memoria común. Junto con esto, la metateatralidad se vuelve central, es decir, la tendencia a la reflexión intelectual y a procedimientos narrativos complejos, como son la estética del montaje/ desmontaje, la deconstrucción, el distanciamiento, todas características comunes que gravitan en torno a esta idea de reconstrucción.

En la configuración del repertorio expuesto en este artículo fueron centrales la espectacularidad, la hibridez y la universalidad de los temas, características que, en cierta forma, facilitan la recepción en contextos culturales diferentes al de origen. Además, la casi inexistente presencia de contenidos estrictamente vinculados a la historia y la cultura chilena constituye una ventaja para estas obras a la hora de ser exhibidas en los escenarios internacionales.

Las características hasta aquí reconocidas a nivel estético nos llevan a pensar que la configuración de un repertorio de exportación permite visualizar en qué modo es valorada una producción en el heterogéneo panorama de los teatros nacionales y, de esta forma, cómo a través de las obras, cada espacio cultural se relaciona con el contexto artístico de acogida. En esta dimensión, resulta interesante pensar las proyecciones de una investigación más extensa donde podría asumirse una perspectiva comparada entre los contextos culturales y artísticos implicados en la internacionalización.

El espacio cultural delineado a través de este repertorio se muestra coherente con un legado teatral occidental debido a su constante referencia a poéticas teatrales posmodernas, posdramáticas y brechtianas. Los procedimientos comunes ya señalados -la fragmentación, la hibridez, la espectacularidad, la problematización del simulacro teatral-desplazan categorías tradicionales y presuponen la colaboración del espectador en la atribución de sentidos a la obra. Creemos que estos aspectos pertenecen en la actualidad a un estado del arte que se interroga por la situación del teatro, sus fines y confines, siempre en constante fluctuación. Entonces, es posible reconocer que la imagen cultural del Chile teatral, proyectada a través de este repertorio, se suma y aporta coherentemente desde su propio espacio cultural a inquietudes que forman parte de una voz común y de una forma de pensamiento actual que sobrepasa las diferencias lingüísticas y geográficas.

Al mismo tiempo, sostenemos que la creación de un repertorio de internacionalización no depende solo de cuestiones estéticas, sino que también implica la convergencia de una serie de variables que entretejen aspectos estéticos y extraestéticos. Su selección y organización están estrechamente ligadas a los rasgos identitarios intrínsecos de las obras, pero también de las instituciones culturales que los delimitan. En este sentido, debemos reconocer que en la interacción de lo artístico, lo económico y lo político accionan preconcepciones, y se construyen sentidos en torno a lo teatral desde lo vivido por cada contexto sociocultural. 


\section{Referencias}

Baudrillard, Jean. Cultura y simulacro. Barcelona: Kairós, 2012. Impreso.

Calderón, Guillermo. "Neva”. Antología: un siglo de dramaturgia chilena, tomo Iv. Eds. María de la Luz Hurtado y Mauricio Barría. Santiago: Publicaciones Comisión Bicentenario, 2010. 307-333. Impreso.

Carvajal, Fernanda y Van Diest, Camila. "La indocilidad del gesto: contaminaciones y quiebres del imaginario del poder: 'Trilogía Pública' del Teatro La María”. Primer Simposio Internacional de Estética y Filosofía: "Espesores de Superficie”. Santiago, Chile, 2007. 95-109. Impreso

De Marinis, Marco. Capire il teatro. Lineamenti di una nuova teatrologia. Roma: Bulzoni, 1988. Impreso.

De Toro, Alfonso "Reflexiones sobre fundamentos de investigación transdisciplinaria, transcultural y transtextual en las ciencias del teatro en el contexto de una teoría postmoderna y postcolonial de la 'hibridez' e 'inter-medialidad'”. Estrategias postmodernas y postcoloniales en el teatro latinoamericano actual. Hibridez- medialidad-cuerpo. Ed. Alfonso de Toro. Fráncfort: Vervuert, 2004. 105-159. Impreso.

Espinoza, Marco, y Miranda, Raúl. Mutaciones escénicas: mediamorfosis, transmedialidad y postproducción. Santiago: RIL, 2009. Impreso.

Infante, Manuela. "Rey planta”. Antología: un siglo de dramaturgia chilena, tomo Iv. Ed. María de la Luz Hurtado y Mauricio Barría. Santiago: Publicaciones Comisión Bicentenario, 2010. 237-257. Impreso.

---. “Cristo: Cuaderno de notas”. Apuntes 130 (2008). 9-14. Impreso.

Jeftanovic, Andrea. "Manuela Infante: La antidramaturga". Antología: un siglo de dramaturgia chilena, tomo Iv. Ed. María de la Luz Hurtado y Mauricio Barría. Santiago: Publicaciones Comisión Bicentenario, 2010. Impreso.

Jenkins, Henry. Cultura convergente. Milan: Apogeo, 2007. Impreso.

Moreno, Alexis y Von Hummel, María José. La tercera obra. Inédito, 2006. Impreso.

Noguera, Héctor y Ruiz, Vicente. Nijinsky (o la mente asesinada). Inédito, 2003. Impreso.

Oyarzún, Carola. "Entre el teatro y la vida”. Antología: un siglo de dramaturgia chilena, tomo IV. Ed. María de la Luz Hurtado y Mauricio Barría. Santiago: Publicaciones Comisión Bicentenario, 2010. 303-305. Impreso.

Pizarro, Laura, et al. El hombre que daba de comer a las mariposas. Inédito, 2010. Impreso.

"Programma delle Rassegne delle Culture Migranti della Provincia di Lecce". Territorios [Lecce, Italia] 2008. 1-34. Impreso.

Richard, Nelly. Residuos y metáforas (Ensayos de crítica cultural sobre el Chile de la Transición). Santiago: Cuarto Propio, 2001. Impreso. 
Schriewer, Jürgen. "Sistema mundial y redes de interrelación: la internacionalización de la educación y el papel de la investigación comparada”. Nueva Época 1 (1997). 21-58. Impreso.

Villegas, Juan. "El teatro chileno de la postdictadura". Inti: Revista de literatura hispánica 69 (2009). 189-205. Impreso.

Zagal, Juan Carlos. “Teatro Cinema, una compañía que se reta a ser original”. El Comercio 13 de noviembre de 2013. Medio impreso.

Recibido: 14 junio 2016

Aceptado: 28 junio 2017 